\title{
同期機における零相・逆相回路間の相互干渉
}

\begin{tabular}{|c|c|c|c|c|c|}
\hline 正 員 & 高 & 瀬 & 冬 & 人 & （京都 大) \\
\hline 非会員 & 朝 & 倉 & 孝 & 宜 & （宗都 大) \\
\hline 正 員 & 松 & 村 & 年 & 郎 & (名古屋大) \\
\hline 員 & 上 & 田 & 脘 & 亮 & （京 都 ～ \\
\hline
\end{tabular}

\section{Mutual Interaction between Zero-Phase-Sequence and Negative-Phase-Sequence Circuits in a Synchronous Generator}

Fuyuto Takase, Member, Takanobu Asakura, Non-member (Kyoto University), Toshiro Matsumura, Member (Nagoya University), Yoshisuke Ueda, Member (Kyoto University)

\begin{abstract}
The mutual interacton between zero-phase-sequence and negative-phase-sequence circuits in a salient pole synchronous generator is proved experimentally and theoretically. In the method of symmetrical coordinates, it has been believed that positive-, negative- and zero-phase-sequence components are independent. But an experiment driving a synchronous generator with unbalanced load shows that negative-phase-sequence voltage is induced when only zero-phase-sequence current is applied. These interaction between negative- and zero-phase- sequence circuits are proved theoretically by magnetic flux distribution in the air-gap of synchronous generator. The $\mathrm{m}$. m. f. by zero-phase-sequence current generates negative-phase-sequence flux distribution by the saliency of the rotor and the field current 2 nd harmonics and vice versa. The revised exprssion for synchronous machine in the symmetric coordinate is proposed.
\end{abstract}

キーワード：対称座標法, 零相, 逆相, 同期機, 空げき磁束, パーミアンス

\section{1.はじめに}

本論文は，対称座標法で記述した同期機において，零相 回路と逆相回路の間に相互干涉があることを実験と理論か ら示し, 慣用の対称座標法における同期機の表現は, 近似 的な表現であることを示すものである。

対称座標法は, 不平衡時の三相交流回路の電圧, 電流を 正相, 逆相, 零相の各対称成分に分解して扱う方法として 知られている(1)。同期機を対称座標法で記述すると各対称 成分は独立している, すなわち正相, 逆相, 零相の電圧 は, 対応する対称成分電流のみから定まるとされている。 しかし，本論文では，対称成分の独立性は撖密には成立し ておらず，一つの近似であることを示す。

著者らは, 逆相電流のみを流した同期機において零相電 圧が発生することをさきに示した ${ }^{(2)(3)}$ 。本論文では, 逆に, 零相電流のみを流した状態で, 逆相電圧が発生することを 実験で確かめる。この逆相電圧は, 供試機では零相電圧の 4 割程度になり，無視できない大きさである。 次に同期機内部の空げき磁束の観点から理論的な検討を 行い,この効果が電機子巻線分布の正弦波からのずれ（空
間高調波)と回転子の突極性により生じることを示す。 更に，対称座標法における同期機の表現について検討し， 零相・逆相間の相互干渉を含めた新しい表現式を提案し, 実験により検証する。

\section{2. 供試発電機}

〈2・1〉供試発電機(5) 実験に用いた同期発電機の断 面を図 1 に示す。供試機は突極機であり，定格は容量 6 $\mathrm{kVA}$, 電压 $220 \mathrm{~V}$, 電流 $15.7 \mathrm{~A}$, 回転速度 $1,800 \mathrm{rpm}$ で ある。制動巻線は装着していない。毎極毎相のスロット数 は3である。電機子歯頭部には探りコイルが巻かれ, 空げ き磁束が観測できる。

〈2・2〉空げき位置を表す座標系空げきの位置を $a$ 相巻線軸を原点し, 回転子の回転方向を正とする変数 $\xi$ (電気角)で表す。時間の原点は, 回転子直軸が $a$ 相巻線 軸に一致する時刻とする。また，回転子上からみた空げき の位置を表す座標 $\eta$ を, $\eta=\xi-\omega t$ (電気角)で定義する。 $\omega$ は電源の角周波数である。

〈2・3〉 対称座標への変換観測した電圧, 電流から 以下の手順で対称成分を算出した。まず電圧，電流の瞬時 


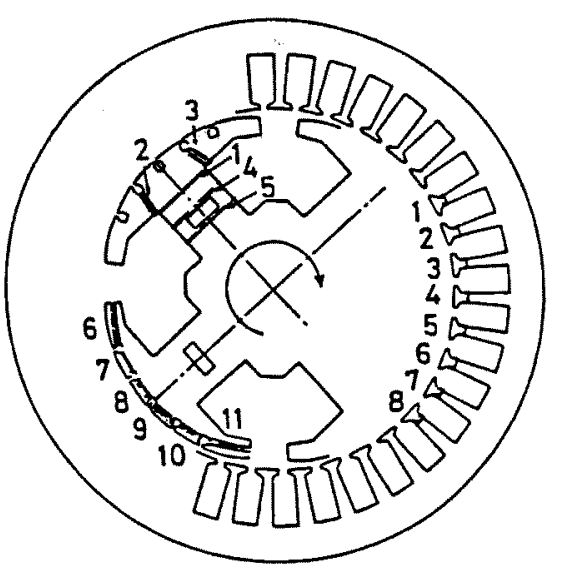

図 1 供試発電機の断面

Fig. 1. Cross section of the tested generator.

值をフーリエ変換し, 基本波成分の振幅 $E$ および位相 $\angle E$ を求めて, ベクトル表示する(電圧についてのみ示す が, 電流も同様)。

$$
\begin{aligned}
& e(t)=\sqrt{2} E \sin (\omega t+\angle E)+\text { 高調波成分 } \\
& \dot{E}=E \exp (j \angle E)
\end{aligned}
$$

対称成分へは，次式に従って分解する(1)。

$$
\left[\begin{array}{l}
\dot{E}_{0} \\
\dot{E}_{1} \\
\dot{E}_{2}
\end{array}\right]=\frac{1}{3}\left[\begin{array}{ccc}
1 & 1 & 1 \\
1 & a & a^{2} \\
1 & a^{2} & a
\end{array}\right]\left[\begin{array}{l}
\dot{E}_{a} \\
\dot{E}_{b} \\
\dot{E}_{c}
\end{array}\right]
$$

ただし, $a=\exp (j 2 / 3 \pi)$

\section{3. 実験方法と実験結果}

〈3・1〉零相電流による逆相電圧の発生 図 2 に実験 回路を示す。電機子巻線は三相分を直列にして, 単相電源に 接統する。各巻線の電流は位相を含めて同一であるから， 零相電流のみが流れる。この接続は，零相インピーダンス の測定法(直列法)として知られている ${ }^{(6)}$ 。同期機の運転法 としては特殊であるが, ここで問題としている零相・逆相 間相互作用の検証には適している。

界磁巻線短絡，定格回転速度の状態で，測定した零相電 圧 $E_{0}$, 逆相電圧 $E_{2}$ を, 零相電流 $I_{0} に$ 対して, 図 $3(\mathrm{a})$ に示す。電機子電流は零相成分のみであるが, 電機子電圧 には，零相成分のみならず逆相分も現れる。逆相電圧と零

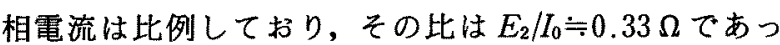
た。この比は, 逆相電流により発生する零相電圧の比 ${ }^{(3)}$ と等しい。

次に，零相電流を $19 \mathrm{~A}$ に保ち，同期機の回転位相を電 源系統にして変化させる ${ }^{(3)}$ 。このとき, 逆相, 零相電圧の 振幅は一定であった。これらの電圧の位相 $\angle E_{2}, \angle E_{0}$ を, 零相電流の位相 $\angle I_{0}$ に対して, (b) 図に示す。零相 電圧と零相電流の位相差は一定である。一方, 逆相電圧と 零相電流の位相は, 和が一定 $\left(\angle E_{2}+\angle I_{0} \fallingdotseq-91^{\circ}\right)$ となっ ている。

またこの実験では，短絡した界磁巻線に第 2 および第 4

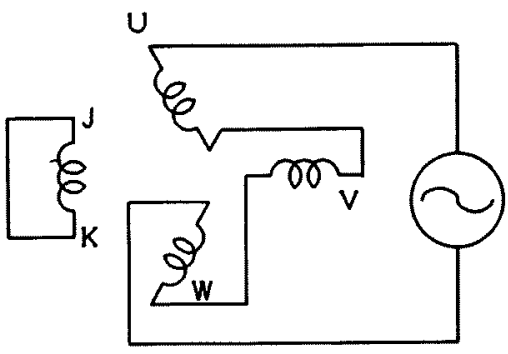

図 2 実験回路

Fig. 2. Experimental circuit.

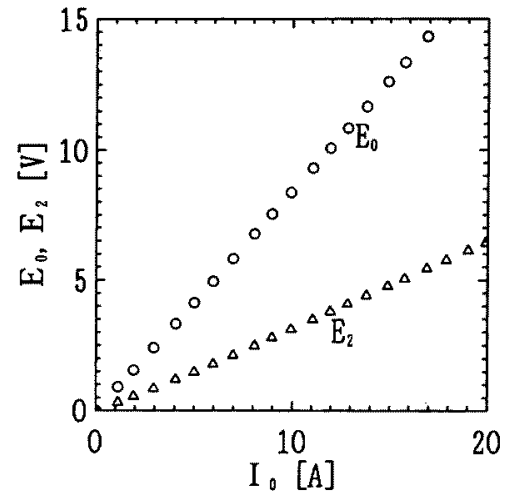

(a) 電圧

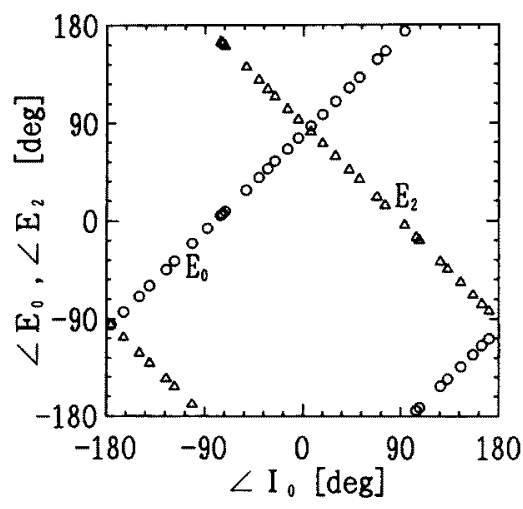

(b) 電压の位相

図 3 零相電流により生じる零相, 逆相電圧 Fig. 3. Zero- and negative-phase-sequence voltages and phases induced by zero-phase-sequence current.

調波電流が発生する。この界磁電流 $i_{f}(t)$ を次式で表す。

$$
\left.\begin{array}{rl}
i_{f}(t)= & \sqrt{2} I_{f 2} \sin \left(2 \omega t+\angle I_{f_{2}}\right) \\
& +\sqrt{2} I_{f 4} \sin \left(4 \omega t+\angle I_{f_{4}}\right)
\end{array}\right\}
$$

実験によると $I_{f 2}, I_{f 4}$ は $I_{0}$ に比例し, 位相は $\angle I_{f 2}+\angle I_{0}$ $\doteqdot 6^{\circ}, \angle I_{f 4}-\angle I_{0} \fallingdotseq 179^{\circ}$ となっている。

〈3・2〉空げき磁束の観測(5) 電機子歯頭部の探りコ イルを用いて，空げき部の磁束密度を観測する。観測した 空げき磁束のうち, 固定子からみた時間基本波成分を, 空 間高調波成分の和に展開する(3)。

$B(\xi, t) \sim \sum_{m} B_{m} \sin \left(\omega t+\angle B_{m}-m \xi\right)$

$B_{m}$ : 空間第 $m$ 次・時間基本波成分 


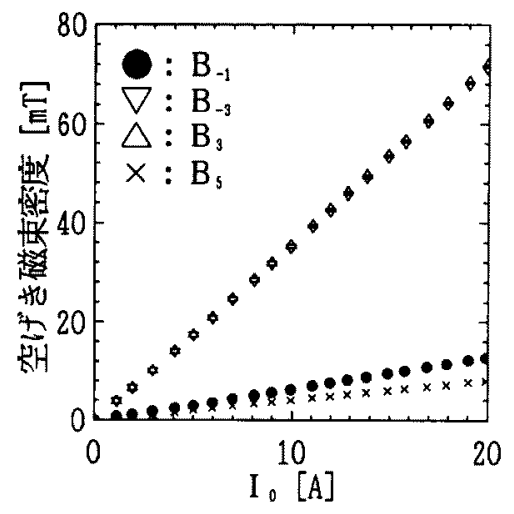

(a) 振 福

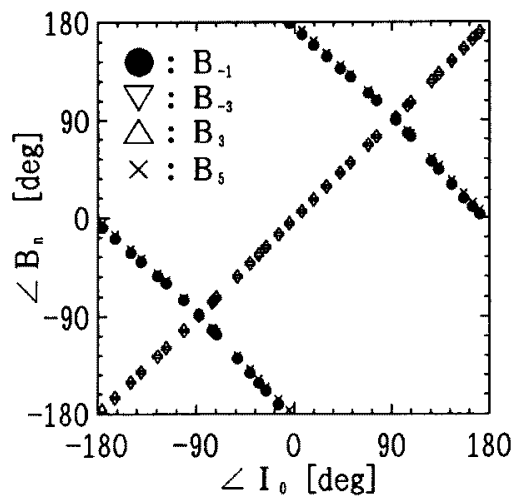

(b) 位 相

図 4 零相電流により発生する磁束密度成分

Fig. 4. Air-gap flux density by zero-phasesequence current.

実験より求めた空げき磁束の空間高調波成分を，図 4 (a) に示す。零相電流に比例して, 空間 3 倍波成分 $B_{3}$, $B_{-3}$, 空間基本 - 逆回転成分 $B_{-1}$ 成分, 空間第 5 調波成分 $B_{5}$ が発生している。これら以外の成分は微小である。

零相電流と空げき磁束の空間高調波成分の位相の関係 は, (b)図に示すように, $\angle B_{3}-\angle I_{0}, \angle B_{-3}-\angle I_{0}, \angle B_{-1}$ $+\angle I_{0}, \angle B_{5}+\angle I_{0}$ が，それぞれ一定となっている。

\section{4. 零相電流による逆相電圧の発生機構}

零相電流から逆相電圧が生じる機構を, 空げき磁束とパ ーミアンスモデル(7)に基づいて説明する。

$\langle 4 \cdot 1\rangle$ 発生機構の概略 発生機構の概略を図 5 に示 す。零相電流 $I_{0}$ と, 電機子巻線分布の空間第三調波成分 によって，空げきに空間第 3 調波起磁力が発生する。これ は，回転子の突極性によりひずみ，磁束分布に空間基本逆 回転成分 $B_{-1}$ を発生する。また零相磁束は, 界磁電流に 第二調波 $I_{f_{2}}$ を誘導し, これも $B_{-1}$ を発生させる。磁束分 布の空間基本逆回転成分は, 電機子巻線に逆相電圧を誘導 する。以下，各部を説明する。

〈4・2〉零相電流による起磁力 電機子電流を, 零相 電流のみが流れた次のかたちにおく。

$$
i_{a}(t)=i_{b}(t)=i_{c}(t)=\sqrt{2} I_{0} \sin \left(\omega t+\angle I_{0}\right)
$$

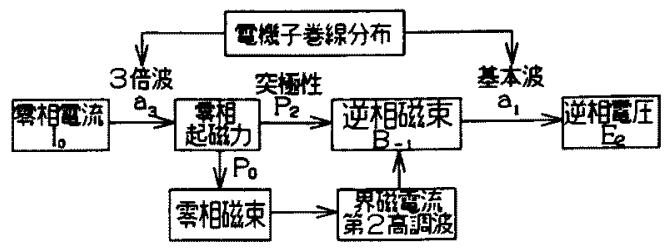

図 5 零相電流による逆相電圧の発生機構

Fig. 5. Induction of negative-phase-sequence voltage from zero-phase-sequence current.

この電流から生じる電機子起磁力 $F_{a m}$ は, 時間基本・空 間第三調波成分(正および逆方向回転)である。

$$
\begin{aligned}
F_{a m}(\xi, t)= & \sqrt{2} I_{0} a_{3} \frac{3}{2}\left\{\sin \left(\omega t+\angle I_{0}+3 \xi\right)\right. \\
& \left.+\sin \left(\omega t+\angle I_{0}-3 \xi\right)\right\} \ldots \ldots \ldots \ldots .
\end{aligned}
$$

係数 $a_{3}$ は, 電機子 $a$ 相巻線の巻線分布の空間第三調波の 係数である(7)。

〈4・3〉突極性により生じる空間 3 倍波空げき部の パーミアンス分布と電機子起磁力を用いて, 空げき磁束密 度は次式で表される。

$$
\begin{aligned}
B(\xi, t)= & F_{a m}(\xi) P(\eta) \\
= & \sqrt{2} I_{0} a_{3} \frac{3}{2} P_{0} \sin \left(\omega t+\angle I_{0}-3 \xi\right) \\
& +\sqrt{2} I_{0} a_{3} \frac{3}{2} P_{0} \sin \left(\omega t+\angle I_{0}+3 \xi\right) \\
& +\sqrt{2} I_{0} a_{3} \frac{3}{4} P_{2} \sin \left(\omega t-\angle I_{0}+\xi+\pi\right) \\
& +\sqrt{2} I_{0} a_{3} \frac{3}{4} P_{2} \sin \left(\omega t-\angle I_{0}-5 \xi+\pi\right) \\
& + \text { 時間に関する高調波成分 }
\end{aligned}
$$

$P(\eta)$ は空げきのパーミアンス， $P_{0}$ は $P(\eta)$ の空間分布 の平均值， $P_{2}$ は突極性を表す係数である ${ }^{(3)}$ 。( 8 )式の第 1 , 第 2 項は空間 3 倍波 $B_{3}, B_{-3}$ を表す。第 3 項は空間 基本波・逆回転成分 $B_{-1}$, 第 4 項は空間 5 倍波 $B_{5}$ を表す項 であり，突極性 $P_{2}$ から生じることがわかる。

$\langle 4 \cdot 4\rangle$ 界磁電流高調波の影響 界磁電流の第二調波 からも，磁束成分 $B_{-1}$ が発生することを示す。まず，界 磁巻線を直流励磁したときの空げき磁束を, 無負荷試験の 結果から次式で表す。

$$
B(\eta)=i_{f}\left\{b_{1} \cos \eta+b_{3} \cos 3 \eta+b_{5} \cos 5 \eta\right\}
$$

界磁巻線に高調波電流 (4) 式が流れると, 次の磁束が発生 する。

$$
\begin{aligned}
& B(\xi, t)=\frac{\sqrt{2}}{2} I_{f 2} b_{3} \sin \left(\omega t-\angle I_{f 2}-3 \xi+\pi\right) \\
& +\frac{\sqrt{2}}{2} I_{f 4} b_{3} \sin \left(\omega t+\angle I_{f 4}+3 \xi\right) \\
& +\frac{\sqrt{2}}{2} I_{f 2} b_{1} \sin \left(\omega t+\angle I_{f 2}+\xi\right) \\
& +\frac{\sqrt{2}}{2} I_{f 4} b_{5} \sin \left(\omega t-\angle I_{f 4}-5 \xi+\pi\right) \\
& + \text { 時間に関する高調波成分 }
\end{aligned}
$$


第 1 ，第 2 項は空間 3 倍波成分 $B_{3}$ ，第 3 項は空間基本 波・逆回転成分 $B_{-1}$ ，第 4 項は空間 5 倍波成分 $B_{5}$ を表して いる。逆相磁束成分である第 3 項は $I_{f_{2}}$ により生じること がわかる。 $I_{f_{2}}$ は零相電流に比例するので, 逆相磁束成分 も塞相電流に比例する。

〈4·5〉 空げき磁束の生成 以上をまとめて，雲相電 流により発生する磁束密度成分 $B_{3}, B_{-3}, B_{-1}$ を計算す る。表 1 に示す諸定数から，磁束成分のパーミアンス寄与 分 (8) 式, 界磁電流奇与分 (10)式とそれらの和(零相電流 $1 \mathrm{~A}$ 当たり)を壾算し，実測值とともに表 2 に示す。位相 に関して $(8) ，(10)$ 式より $\angle B_{3}-\angle I_{0}$ などの和または差 が一定となる。この傾向は実験結果と一致するので,これ らの值を表に示す。理論的に求めた空げき磁束密度が，実 測值とよく一致していることがわかる。

以上より，空げき磁束分布に，逆回転成分 $B_{-1}$ が発生 することを，理論的に説明できた。

〈4-6〉電压対称成分と磁束分布空げき磁束と電機 子巻線鎖交磁束の関係を用いると，逆回転成分 $B_{-1}$ から 逆相電圧が生じ，空間 3 倍成分 $B_{3}, B_{-3}$ から雲相電压が 生じることがわかる(7)。

磁束密度分布の測定值より電機子電圧を計算し，実測值

表 1 供試機の諸定数

Table 1. Constants of the tested generator.

$\begin{array}{ll}P_{0}=0.214 & \mathrm{mT} / \mathrm{A} \\ P_{2}=0.064 & \mathrm{mT} / \mathrm{A} \\ b_{1}=147 & \mathrm{mT} / \mathrm{A} \\ b_{\mathrm{s}}=-25 & \mathrm{mT} / \mathrm{A} \\ b_{3}=2.6 & \mathrm{mT} / \mathrm{A} \\ I_{f_{2}} / I_{0}=1.92 \times 10^{-3} & \mathrm{~A} / \mathrm{A} \\ I_{f_{4}} / I_{0}=1.86 \times 10^{-3} & \mathrm{~A} / \mathrm{A} \\ a_{3}=-5.88 & \text { ターン }\end{array}$

表 2 空げき磁束密度の理論值と実測值

Table 2. Air-gap flux density by zero-phasesequence current.

\begin{tabular}{c|cc|cc}
\hline & $\begin{array}{c}\text { パーミアンス } \\
\text { 寄与分 } \\
(\mathrm{mT} / \mathrm{A})\end{array}$ & $\begin{array}{c}\text { 界磁電流 } \\
\text { 奇与分 } \\
(\mathrm{mT} / \mathrm{A})\end{array}$ & $\begin{array}{c}\text { 理諭值 } \\
\text { (和) } \\
(\mathrm{mT} / \mathrm{A})\end{array}$ & $\begin{array}{c}\text { 実踟值 } \\
(\mathrm{mT} / \mathrm{A})\end{array}$ \\
\hline$B_{3} / I_{0}$ & 2.67 & 0.03 & 2.64 & 3.63 \\
$\angle B_{3}-\angle I_{0}$ & $\pi$ & 0 & $\pi$ & $-179^{\circ}$ \\
$B_{-3} / I_{0}$ & 2.67 & 0.03 & 2.64 & 3.59 \\
$\angle B_{-3}-\angle I_{0}$ & $\pi$ & 0 & $\pi$ & $178^{\circ}$ \\
$B_{-1} / I_{0}$ & 0.40 & 0.20 & 0.60 & 0.66 \\
$\angle B_{-1}+\angle I_{0}$ & 0 & 0 & 0 & $-1^{\circ}$ \\
$B_{5} / I_{0}$ & 0.40 & 0.003 & 0.40 & 0.41 \\
$\angle B_{5}-\angle I_{0}$ & 0 & 0 & 0 & $2^{\circ}$ \\
\hline
\end{tabular}

表 3 零相電流による逆相，零相電圧

Table 3. Negative- and ziro-phase-sequence voltages.

\begin{tabular}{c|c|c}
\hline & 計算值 $(\Omega)$ & 実測値 $(\Omega)$ \\
\hline$E_{0} / I_{0}$ & 0.64 & 0.85 \\
$E_{2} / I_{0}$ & 0.29 & 0.33 \\
\hline
\end{tabular}

とともに表 3 に示す。計算值は実測值とほほ一致してい

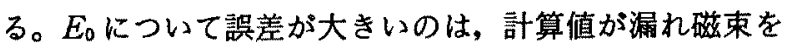
考慮していないためと考えられる。

以上のように，零相電流から逆相電圧が生じる機構とし て，零相電流から空げき部に空間第三調波起磁力分布が発 生し，これが回転子の突極性や界磁高調波電流によって空 間基本波の磁束分布に変換されて，逆相電圧となることを 示した。

\section{5. 対称座標法における同期機の表現式の修正}

〈5・1〉 同期機の表現式の修正 以上の結果をまとめ て，対称座標法における同期機の表現式を修正する。

同期機の端子電圧の対称座標成分 $\dot{E}_{1}, \dot{E}_{2}, \dot{E}_{0}$ と, 電機 子電流の対称座標成分 $\dot{I}_{1}, \dot{I}_{2}, \dot{I}_{0}$ の関係を, 次式(対称座 標法に招ける同期機の表現式)で表す。 $\dot{Z}_{02}, \dot{Z}_{20}$ が, 新た に追加された項であり，零相・逆相間の相互作用を表して いる。

$$
\left.\begin{array}{l}
\dot{E}_{1}=\dot{E}_{10}-\dot{Z}_{1} \dot{I}_{1} \\
\dot{E}_{2}=-\dot{Z}_{2} \dot{I}_{2}-\dot{Z}_{20} \overline{I_{0}} \\
\dot{E}_{0}=-\dot{Z}_{0} \dot{I}_{0}-\dot{Z}_{02} I_{2}
\end{array}\right\}
$$

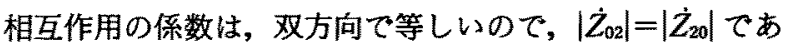
る。また一は, 複素共役であり, 電流と電圧の位相の和が 一定となる位相関係を表現している。供試機では $Z_{2}=$ $3.96 \Omega, Z_{0}=0.85 \Omega, Z_{02}=Z_{20}=0.33 \Omega$ である。

〈5・2〉同期鈛の表現式の検証 対称座摽法における 同期機の表現式(11)式の妥当性を検証するため, 図 6 に示 す回路で実験を行った。電機子巻線の $b$ 相 $-c$ 相間に負荷 $Y_{b c} ａ$ 相一中性点間に負荷 $Y_{a}$ (ともに力率 0.1 遅れ) 接 続する。

図 6 の回路で，界磁を一定電圧で励磁し，同期機を定格 速度で運転する。| $Y_{b c} \mid$ を変化させながら，各部の電圧， 電流を測定する。このとき，Iaの実効值が一定となるよ うに $\left|Y_{a}\right|$ を調整する。 $I_{f}=1.5 \mathrm{~A}, I_{a}=15 \mathrm{~A}$ の場合を図 7 に示す。

この回路では $I_{a}=3 \cdot I_{0}$ となるので, 零相電流 $I_{0}$ は一定 に保たれる。しかし，実測した雾相電圧 $E_{0}$ は，図 7 に示 すように変化する。これは，零相・逆相相互作用から説明 できる。 $I_{0}, I_{2}$ の実測值を(11)式に代入して，従来の表現 式と， $Z_{02}$ 考慮した式による $E_{0}$ の計算值を図 7 に併せ

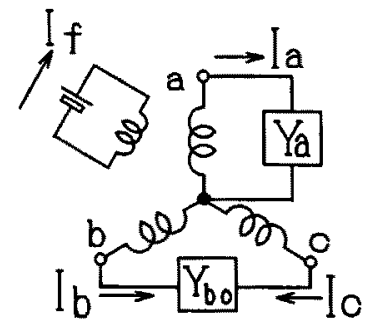

図 6 実験回路

Fig. 6. Experimental circuit. 


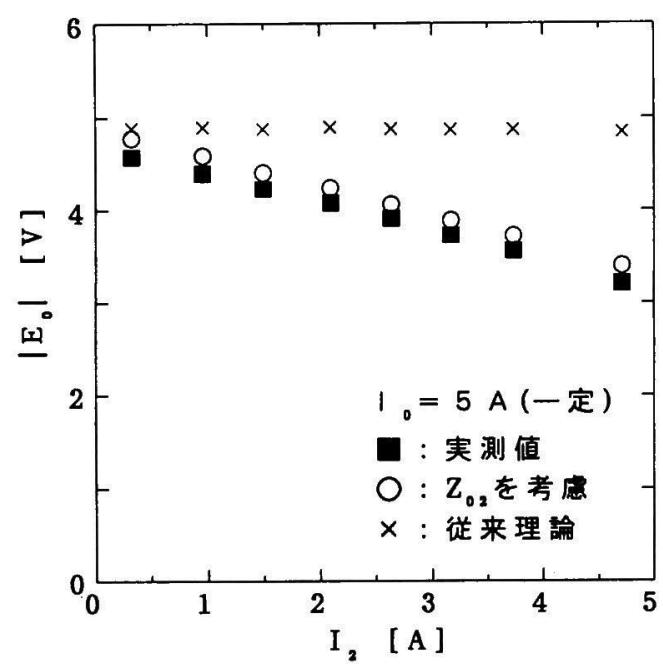

図 7 修正した表現式と従来の表現式の比較

Fig. 7. Comparison between revised expression and conventional expression.

て示す。従来理論では $E_{0}$ の変化を説明できないが, 零 相・逆相相互作用を考慮すると実測值の変化を説明できる ことがわかる。

\section{6.むすび}

同期機において零相回路と逆相回路の間に，相互干涉が 生じることを実験的・理論的に示した。

従来の対称座標法では, 同期機の逆相成分と零相成分は 独立しているとされてきた。しかし，同期機を不平衡状態 で運転した実験の結果, ある突極機において, 零相回路と 逆相回路が相互干涉することが明らかになった。すなわ ち, 電機子巻線に零相電流のみを流した状態で逆相電圧が 発生することを示した。この現象と，さきに示した逆相電 流による零相電圧の発生を考え合わせると, 逆相, 零相回 路間に相互作用があることが明らかになった。このとき， 逆相電流から零相電圧への比例係数と, 零相電流から逆相 電圧への比例係数は等しくなる。

次に, この干渉の発生機構について, 同期機内部の空げ き磁束の観点から理論的な検討を行った。すなわち，電機 子巻線分布が空間第三調波成分を含むとき, 零相電流から 時間基本・空間第三調波起磁力が発生する。この起磁力か ら，回転子の突極性および界磁電流第二調波により，空げ き磁束に時間基本・逆回転成分が発生する。この磁束分布 成分が，電機子線に鎖交して逆相電圧となることを理論的 に示した。理論的に計算された値は，実験值とよく一致し 理論の妥当性を示している。

更に, 対称座標法における同期機の表現について, 本論 文の効果を表す項を付加した表現式を提案し, 実験により 検証した。なお，本論文は制動巻線がない場合を述べた。 制動巻線があると逆相磁界に対する突極性が小さくなるた め, 逆相・零相間の相互作用は小さくなると予想される。
その検証は今後の課題である。

(平成 5 年 1 月 26 日受付，同 5 年 6 月 3 日再受付)

\section{文献}

（1）例えば，上之園：現代電力工学（昭 55）オーム社

（2）上田・朝會・引原:「不平衡負荷時における同期発電機の特性に関 する一考察」, 電気学会回転機研資, RM 88-12 (昭 63)

（3）高瀬・朝倉・引原・松村・上田：「同期機の逆相電流により生じる 零相電圧」, 電学椧 D, 113, 381 (平 5)

（4）上田・朝倉・引原:「突極型同期機の電機子巻線構造から生じる対 称分回路間の相互干涉」, 昭 63 電気関係学会関西支部連大, G 163

（5）上之園・上田・七原・金子：「定態時に扔ける同期発電機の空げき 磁束とそれに基づく特性解析」，電学論 B，102，281（昭 57）

（6）「同期機試験法要綱」, 電学技報 (II部), No. 18 (昭 47)

（7）高瀬・松村・上田:「パーミアンスによるギャップ磁束密度算定手 法に基づく同期発電機モテル」，電学論 D，111，865（平 3)

高 瀬 冬人 (正員) 1956 年 3 月 3 日生。 1983 年京都大学大 学院工学研究科博士課程修了。同年(株) 日立製 作所入所。1986 年京都大学助手。工学博士。主 として, 電子回路の非線形現象の研究, メカト ロニクスの制御系の研究，同期機の空げき磁束 の研究に従事。

宜 (非会員) 1964 年 5 月 8 日生。1989 年京都大学 大学院工学研究科修士課程修了。在学中, 同期 機の不平衡運転時の特性を研究。現在, 関西電 力 (株) 勤務。

松 村 年 郎 (正員) 1951 年 5 月 1 日生。 1979 年名古屋大学

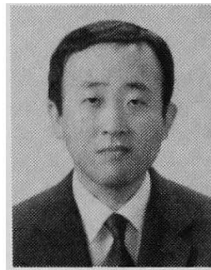
大学院工学研究科博士課程修了。同年同大学助 手, 1987 年同講師, 1989 年京都大学講師, 1992 年名古屋大学助教授, 現在に至る。工学博士。 主として，大電流および電気エネルギーの有効 利用に関する研究。回転機空げき磁束の挙動に 関する研究に従事。

上田睆亮 (正員) 1936 年 12 月 23 日生。1964 年京都大学

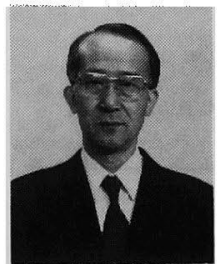
大学院工学研究科博士課程修了。同年同大学助 手, 1967 年講師, 1971 年助教授, 1985 年教授。 工学博士。主として, 電気・電子回路における非 線形現象の研究, 空げき磁束からみた回転電気 機械の諸特性に関する研究に従事。 